\title{
Identification of a novel enterotoxigenic activity associated with Bacillus cereus
}

\author{
J. MELLING, B. J. CAPEL, P. C. B. TURNBULL, AND R. J. GILBERT \\ From the Microbiological Research Establishment, Porton Down, Salisbury, Wiltshire and \\ the Central Public Health Laboratory, Colindale Avenue, London NW9 5HT
}

SYNOPSIS A strain of Bacillus cereus isolated from a food poisoning outbreak characterized by vomiting has been shown to be capable of causing vomiting when cultures grown on rice, but notio other media, were fed to Rhesus monkeys. In contrast, a strain isolated from a diarrhoeal outbreakproduced diarrhoea, but not vomiting, when grown on various media in similar feeding trials $i_{5}$ Furthermore, culture filtrates from the diarrhoeal strain caused fluid accumulation in ligated rabbitoo ileal loops whereas those from the vomiting strain did not. It is proposed that at least two enterotoxins are involved, one responsible for the vomiting and one for the diarrhoeal symptoms.

Bacillus cereus has been implicated in food poisoning outbreaks since early this century (Lubenau, 1906) but it was not until after 1950 that the by now classic description of $B$. cereus gastroenteritis was made (Hauge, 1950; 1955; Goepfert et al, 1972). The illness was characterized by symptoms of diarrhoea and abdominal pain between 8 and 16 hours after ingestion of food; vomiting was rare. A wide variety of foods has been involved including meat and vegetable soups, cooked meat and poultry, cooked vegetables, puddings, and sauces. An enterotoxin from $B$. cereus strains isolated from such incidents has been partially characterized (Spira and Goepfert, 1975).

Since 1971, however, numerous incidents of food poisoning associated with consumption of cooked rice from Chinese restaurants and 'take-away' shops have been reported in this country as well as in Australia, Canada, and the Netherlands (Taylor and Gilbert, 1975). Although these outbreaks were also attributed to B. cereus(Mortimer and McCann, 1974; Gilbert and Taylor, 1975), the characteristic features were acute nausea and vomiting, usually occurring between 1 and 5 hours after a meal; diarrhoea was not a common feature.

Monkey feeding trials have therefore been carried out in an attempt to confirm that these recent riceassociated outbreaks were in fact caused by $B$. cereus and to determine whether or not a new enterotoxigenic material was involved.

Received for publication 12 April 1976

\section{Material and methods}

ORGANISMS

Three strains of $B$. cereus were used. Strain 4810 (formerly strain 88) was originally isolated frọm vomitus and had been implicated in a typical rices associated illness. Strain $4433 / 73$ had been isolatedh from meat loaf and was implicated in a typica diarrhoeal food poisoning outbreak. The serology of these strains has been described (Taylor and Gilbert, 1975). Strain 2532B/74 was isolated from raw rice and had not been implicated in any food poisoning out break and was non-typable according to the scheme of Taylor and Gilbert (1975).

\section{SEROTYPING}

Serotyping was carried out by the method of Tayloro and Gilbert (1975).

\section{CULTURE METHODS}

For rice cultures $100 \mathrm{~g}$ of ordinary cooking rice(shor? grain) was soaked in $400 \mathrm{ml}$ of $0.95 \%$ saline in 2-litro flasks and autoclaved at $115^{\circ} \mathrm{C}$ for 15 minutes. The rice was inoculated with $30 \mathrm{ml}$ of an 8-hour culture of $B$. cereus in tryptone soya broth and incubated at $30^{\circ} \mathrm{C}$ for $18-20$ hours. The rice culture was theno homogenized with $30 \mathrm{ml}$ of $0.5 \%$ diastase in acetate buffer pH 5.0 to produce a creamy liquor which was dialysed with $10 \%$ carbowax for 24 hours at $4^{\circ} \mathrm{C} \stackrel{\oplus}{?}$ The concentrate was used for monkey feedingo experiments.

Liquid cultures were grown in media containing 
Protein Hydrolysate Powder 3\% (Mead Johnson, USA) and NZ Amine NAK 3\% (Sheffield Chemical Co, USA) with and without $5 \%$ soluble starch.

\section{ASSESSMENT OF EMETIC AND DIARRHOEAL RESPONSES}

Emetic and diarrhoeal activities of cultures were assessed by feeding young (approx $3 \mathrm{~kg}$ ) Rhesus monkeys (Macaca mulatta) with between 100 and $150 \mathrm{ml}$ volumes of the material. The animals were anaesthetized by intramuscular injection of ketamine $\mathrm{HCl}(10 \mathrm{mg} / \mathrm{kg})$ and the test material was administered per os via a lubricated feeding tube. Recovery from the anaesthetic occurred within 30 minutes. Emetic activity was defined as the occurrence of vomiting within 5 hours from feeding and diarrhoea by the presence of watery or loose stools within 24 hours.

\section{LIGATED RABBIT ILEAL ASSAYS}

The ability of filtrates from cultures grown in brain heart infusion broth to cause fluid accumulation in ligated rabbit ileal loops was assessed by the methd of De and Chatterje (1953). Before being tested the filtrates were concentrated approximately12-15 fold by dialysis with carbowax.

\section{Results}

\section{EMETIC ACTIVITY}

The emetic acitivity of the three $B$. cereus strains grown in the various media is shown in table I. In the case of the rice cultures the volumes fed were adjusted so that on each occasion a total of about $1 \times 10^{10}$ viable organisms was fed. In the case of broth culture about $1 \times 10^{11}$ viable organisms were fed. Clearly, the occurrence of vomiting is restricted to the rice cultures of strain 4810 despite the administration of higher cell numbers of broth-grown bacteria. Feeding $150 \mathrm{ml}$ volumes of uninoculated media had no adverse effects.

\begin{tabular}{lllll}
\hline $\begin{array}{l}\text { Culture } \\
\text { medium }\end{array}$ & \multicolumn{3}{l}{ No. of animals which vomited/no. fed } \\
\cline { 2 - 4 } & B. cereus strain & $\begin{array}{l}\text { Uninoculated } \\
\text { medium }\end{array}$ \\
\cline { 2 - 4 } & 4810 & 4433 & $2532 B$ & \\
\hline Rice & $10 / 24$ & $0 / 10$ & $0 / 8$ & $0 / 8$ \\
$\begin{array}{l}\text { PHP/NAK } \\
\text { PHP/NAK }\end{array}$ & $0 / 8$ & $0 / 4$ & $0 / 4$ & $0 / 4$ \\
starch & $0 / 4$ & $0 / 4$ & $0 / 4$ & $0 / 4$ \\
\hline
\end{tabular}

Table I Vomiting response of Rhesus monkeys after oral administration of Bacillus cereus cultures

DIARRHOEAL ACTIVITY

The diarrhoeal activity of the various cultures is shown in table II, and these results were obtained

\begin{tabular}{lllll}
\hline $\begin{array}{llll}\text { Culture } \\
\text { medium }\end{array}$ & \multicolumn{3}{l}{ No. of animals with diarrhoea/no. fed } \\
\cline { 2 - 4 } & \multicolumn{2}{l}{ B. cereus strain } & $\begin{array}{c}\text { Uninoculated } \\
\text { medium }\end{array}$ \\
\cline { 2 - 5 } & 4810 & 4433 & $2532 B$ & \\
\hline $\begin{array}{l}\text { Rice } \\
\text { PHP/NAK }\end{array}$ & $1 / 24$ & $6 / 10$ & $0 / 8$ & $0 / 8$ \\
PHP/NAK + & $1 / 4$ & $0 / 4$ & $0 / 4$ \\
starch & $0 / 4$ & $2 / 4$ & $0 / 4$ & $0 / 4$ \\
\hline
\end{tabular}

Table II Diarrhoeal response of Rhesus monkeys following oral administration of Bacillus cereus cultures

from the same experiments as those in table I. In this case diarrhoeal activity, although largely confined to strain 4433, was present in both rice and broth cultures.

\section{FAECAL EXAMINATION}

An examination of faecal specimens collected 12-24 hours after feeding was made. A typical set of results is shown in table III where the bacteriological picture accurately reflected the material fed.

\begin{tabular}{|c|c|c|c|c|c|}
\hline \multirow{3}{*}{$\begin{array}{l}\text { Animal } \\
\text { no. }\end{array}$} & \multicolumn{2}{|l|}{ Feed } & \multicolumn{3}{|l|}{ Faeces } \\
\hline & \multirow{2}{*}{$\begin{array}{l}\text { Strain of } \\
\text { B. cereus }\end{array}$} & \multirow[t]{2}{*}{ Serotype } & \multicolumn{2}{|c|}{ B. cereus count/g } & \multirow{2}{*}{$\begin{array}{l}\text { Serotype of } \\
\text { B. cereus }\end{array}$} \\
\hline & & & $\begin{array}{l}\text { Before } \\
\text { feeding }\end{array}$ & $\begin{array}{l}\text { After } \\
\text { feeding }\end{array}$ & \\
\hline $\begin{array}{l}16 \\
18 \\
21 \\
20 \\
68 \\
72\end{array}$ & $\begin{array}{l}\text { Rice only } \\
\text { Rice only } \\
4810 \\
4810 \\
2532 B \\
2532 B\end{array}$ & $\begin{array}{l}- \\
- \\
1 \\
1 \\
\text { NT } \\
\text { NT }\end{array}$ & $\begin{array}{l}\text { nil } \\
\text { nil } \\
\text { nil } \\
\text { nil } \\
\text { nil } \\
\text { nil }\end{array}$ & $\begin{array}{l}<100 \\
<100 \\
1.2 \times 10^{\circ} \\
6.2 \times 10^{6} \\
1.1 \times 10^{6} \\
1.3 \times 10^{6}\end{array}$ & $\begin{array}{l}\text { NT } \\
\text { NT } \\
1 \\
1 \\
\text { NT } \\
\text { NT }\end{array}$ \\
\hline
\end{tabular}

Table III Bacillus cereus counts on Rhesus monkey faeces before and after feeding rice cultures

NT = untypable.

\section{LIGATED RABBIT ILEAL ASSAYS}

The diarrhoeal activity of a number of organisms has been correlated with the ability of their culture filtrates to cause the accumulation of fluid in the rabbit loop test. The results from an examination of the three strains used in the feeding trials are shown in table IV. There is a clear difference between the vomiting strain (4810) and the diarrhoeal strain (4433). Although the raw rice strain (2532B) produced a high number of loop positives, it appears

\begin{tabular}{lllc}
\hline $\begin{array}{l}\text { B. cereus } \\
\text { strain }\end{array}$ & Serotype & No. of tests & $\begin{array}{l}\text { No. of loop } \\
\text { positives }\end{array}$ \\
\hline 4810 & 1 & 13 & 2 \\
4433 & 2 & 15 & 12 \\
$2532 B$ & NT & 12 & 9 \\
\hline
\end{tabular}

Table IV Ligated rabbit ileal loop tests of culture filtrates of Bacillus cereus strains

${ }^{1}$ A positive result was defined as one where the ratio of the volume of accumulated fluid $(\mathrm{ml})$ to loop length $(\mathrm{cm})$ exceeded 0.3 . 
from recent work (Turnbull, 1976) that strains which actually produce diarrhoea exhibit the ability to stimulate adenylate cyclase activity as well as giving loop positives. Strain 2532B did not stimulate adenylcyclase activity, but strain 4433 did.

\section{Discussion}

The production of vomiting, but not diarrhoea, in monkeys fed with pure cultures of a $B$. cereus strain (4810), which was originally isolated from a food poisoning outbreak characterized by vomiting, provides confirmation of the epidemiological findings and clearly implicates $B$. cereus with this type of food poisoning. The additional observation that the strain derived from an outbreak of diarrhoeal-type $B$. cereus food poisoning produced diarrhoea, but not vomiting, in the feeding tests provides strong support for the suggestion that a novel enterotoxin is responsible for causing vomiting. The difference between the enterotoxigenic activities of the two strains is reinforced by the results of the rabbit loop tests.

A further distinction between the vomiting and the diarrhoeal strains is reflected in the culture medium specificity for the production of enterotoxigenic activity (tables I and II). Formation of the diarrhoeal toxin occurred in all the culture media while vomiting was produced only in rice culture. This is in accord with epidemiological findings where the range of foods involved in diarrhoeal outbreaks was wide whereas vomiting outbreaks have been restrict to the consumption of rice.

Our aim is to characterize and eventually isolate the vomiting toxin with a view to facilitatin the investigation of outbreaks of food poisoning involving $B$. cereus.

\section{References}

De, S. N. and Chatterje, D. N. (1953). An experimental study of the mechanism of action of Vibrio cholerae on the intestinal mucous membrane. J. Path. Bact., 66, 559-562-

Gilbert, R. J. and Taylor, A. J. (1975). Das Auftreten von Bacillus cereus-Lebensmittelvergiftungen in Grossbrit tannien. Arch. Lebensmitt.-Hyg., 26, 38.

Goepfert, J. M., Spira, W. M., and Kim, H. U. (1972 Bacillus cereus: food poisoning organism. A review. Milk Fd. Technol., 35, 213-227.

Hauge, S. (1950). Food poisoning caused by Bacillus cereus: preliminary report. (In Norwegian). Nord. hyg. T., 31, $18 \overline{\mathrm{g}}$ 206.

Hauge, S. (1955). Food poisoning caused by aerobic spor $\mathscr{E}^{-}$ forming bacilli. J. appl. Bact., 18, 591-595.

Lubenau, C. (1906). Bacillus peptonificans als Erreger eineํㅜㄹ Gastroenteritis-Epidemie. Zbl. Bakt.I. Abt., Orig., 40, 433 437.

Mortimer, P. R. and McCann, G. (1974). Food-poisonir episodes associated with Bacillus cereus in fried rice. Lances 1, 1043-1045.

Spira, W. M. and Goepfert, J. M. (1975). Biological character. istics of an enterotoxin produced by Bacillus cergus Canad.J. Microbiol., 21, 1236-1246.

Taylor, A. J. and Gilbert, R. J. (1975). Bacillus cereus poisoning: a provisional serotyping scheme. $J$. Microbiol., 8, 543-550.

Turnbull, P. C. B. (1976). Studies on the production enterotoxins by Bacillus cereus. J. clin. Path., 29, 941-948 